\title{
WEED INFESTATION OF CROPS OF WINTER SPELT WHEAT (Triticum aestivum ssp. spelta) CULTIVARS GROWN UNDER DIFFERENT CONDITIONS OF MINERAL FERTILIZATION AND CHEMICAL PLANT PROTECTION
}

\author{
Sylwia Andruszczak, Piotr Kraska, Ewa Kwiecińska-Poppe, Edward Pałys \\ Department of Agricultural Ecology, University of Life Sciences in Lublin \\ Akademicka 13, 20-950 Lublin, Poland \\ e-mail: sylwia.andruszczak@up.lublin.pl
}

Received: 27.02 .2012

\begin{abstract}
A field experiment was carried out in the years 20082010 on rendzina soil. The aim of the study was to evaluate weed infestation of winter spelt cultivars ('Schwabenkorn' and 'Spelt I.N.Z.') grown under different conditions of mineral fertilization and chemical plant protection. In the experiment, two levels of mineral fertilization were compared $\left(\mathrm{kg} \times \mathrm{ha}^{-1}\right)$ : I. N 60; P 26.2; K 83; and II. N 80; P 34.9; K 99.6. The chemical protection levels were as follows: A. Control treatment; B. Mustang 306 SE, Stabilan 750 SL; C. Mustang 306 SE, Attribut 70 WG, Stabilan 750 SL; D. Mustang 306 SE, Attribut 70 WG, Alert 375 SC, Stabilan 750 SL.

Apera spica-venti, Setaria pumila, and Galium aparine occurred in greatest numbers in the spelt wheat crop. The cultivar 'Schwabenkorn' was more competitive against weeds. The number of dicotyledonous and monocotyledonous weeds, their total number, and air-dry weight of weeds in the crop of this cultivar were significantly lower compared to cv. 'Spelt I.N.Z.'. Chemical protection of spelt wheat decreased weed dry weight compared to the control treatment without chemical protection. The application of higher rates of mineral fertilizers slightly increased the number of weeds but did not influence their dry weight and number of weed species.
\end{abstract}

Key words: spelt, weed communities, agnotechnical factors

\section{INTRODUCTION}

One of the main factors that reduce crop yields is the presence of weeds. Segetal weeds are characterized by high vigour, they grow faster than crop plants, produce more seeds, and adapt more easily to adverse habitat conditions. If they occur in large numbers, weeds gain a significant advantage over the crop plant, it is therefore very important to select an appropriate and effective weed control method (A d a m c zew ski and Praczy k, 1999). Many studies have been devoted to explain the relationship between the level of chemical crop protection and weed infestation of crop fields. These studies show that weed infestation increases with a decrease in the intensity of chemical plant protection, hence there arises a need to use more intensive crop protection treatments. Other weed control options are now gaining an ever greater importance, including the use of genetic properties of crop plant varieties, in particular their suppressive effect on weeds (J ę d r u s z c z a k et al. 2004; Le merle et al. 1996; B ere s et al. 2010). The literature shows that individual crop plant varieties differ in their ability to compete with weeds (L e m e r le et al. 1996; Feledyn-Szewczyk and Duer, 2005), which is primarily determined by the variation in traits such as emergence rate and biomass accumulation, plant height, tillering rate, or leaf area and leaf angle (Christensen, 1995; S ulewska, 2004; Fe le dyn-Szewczyk and Duer 2006). The above-mentioned characters determine the amount of photosynthetically active radiation penetrating through the crop canopy which directly affects weed growth. Many authors are of opinion that more intensive mineral fertilization is a factor that reduces weed infestation of crops (B l e c h a r c z y k et al. 2009; K r a s k a and $P$ a y s, 2007). Higher NPK rates, through their beneficial effect on crop density, reduce the number and air-dry weight of weeds and differentiate their floristic composition. In turn, the studies of $\mathrm{G}$ a w ron s k a - Kulesza et al. (2005) and Pałys et al. (2011) 
found mineral fertilization to have a stimulating effect on weed infestation of winter wheat.

Due to the constantly growing interest in spelt wheat cultivation, it is advisable to seek varieties of this species that are less susceptible to weed pressure. German spelt cultivars can be mostly found in cultivation, hence the knowledge of their responses to different crop protection and fertilization options under the soil and climatic conditions of Poland may allow us to make recommendations for agricultural practice. The aim of the present study was to compare weed infestation of crops of two winter spelt wheat cultivars grown under different conditions of chemical plant protection and mineral fertilization.

\section{MATERIALS AND METHODS}

A field study was carried out in the period 20082010 in the Bezek Experimental Farm located near the city of Chełm $\left(51^{\circ} 19^{\prime} \mathrm{N} 23^{\circ} 26^{\prime} \mathrm{E}\right)$. The experiment was established on mixed rendzina soil derived from chalk rock, with the granulometric composition of medium silty loam. The soil was characterized by alkaline $\mathrm{pH}$

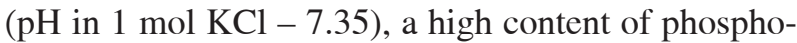
rus (117.8 mg $\times \mathrm{kg}^{-1}$ of soil) and potassium $(242.4 \mathrm{mg}$ $\times \mathrm{kg}^{-1}$ of soil) as well as a very low content of magnesium (19.0 mg $\times \mathrm{kg}^{-1}$ of soil). Organic carbon content was $2.47 \%$. Common wheat was the previous crop for spelt wheat. Tillage was performed in accordance with generally accepted agricultural practice recommendations for winter common wheat. Spelt ears were sown in mid-October at a rate of $350 \mathrm{~kg}$ per hectare. The experiment was set up in a randomized block design in triplicate, in $8 \mathrm{~m}^{2}$ plots. The experimental design included 2 spelt wheat cultivars ('Schabenkorn' and 'Spelt I.N.Z.'), 2 levels of mineral fertilization, and 4 levels of plant protection.

Mineral fertilization was as follows $\left(\mathrm{kg} \times \mathrm{ha}^{-1}\right)$ : I. N 60 (20+40); P 26.2; K 83; II. N $80(20+40+20)$; $\mathrm{P}$ 34.9; K 99.6. Phosphorus and potassium fertilizers as well as $20 \mathrm{~kg} \mathrm{~N} \times \mathrm{ha}^{-1}$ were applied before sowing spelt wheat. In the spring at the stem elongation stage (BBCH 32-34), an amount of $40 \mathrm{~kg} \mathrm{~N} \times$ ha $^{-1}$ was applied in both fertilization treatments. In the treatment with the second level of fertilization, an amount of $20 \mathrm{~kg} \mathrm{~N} \times \mathrm{ha}^{-1}$ was additionally incorporated into the soil at the heading stage (BBCH 52-55).

Plant protection levels included the following treatments: A. Control treatment (without chemical protection); B. Mustang 306 SE + Stabilan 750 SL; C. Mustang $306 \mathrm{SE}+$ Attribut $70 \mathrm{WG}+$ Stabilan 750 SL; D. Mustang 306 SE + Attribut 70 WG + Alert 375 SC + Stabilan 750 SL. The herbicides Mustang $306 \mathrm{SE}$ (florasulam $6.25 \mathrm{~g} \times \mathrm{l}^{-1} ; 2$,4-D EHE $300 \mathrm{~g} \times \mathrm{l}^{-1}$ ) and Attribut $70 \mathrm{WG}$ (propoxycarbazone 70\%; methyl ester of 2-benzoic acid sodium salt) were applied at the tillering stage (BBCH 23-25) at the rates of $0.41 \times$ ha $^{-1}$ and $60 \mathrm{~g} \times \mathrm{ha}^{-1}$, respectively. The fungicide Alert 375

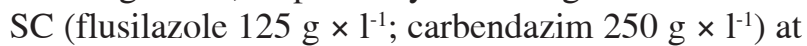
a rate of $11 \times$ ha $^{-1}$ and the growth regulator Stabilan 750

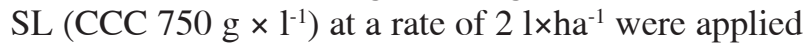
at the stem elongation stage (BBCH 32-34).

Weed infestation was evaluated by the quantitative gravimetric method at the dough stage (85-87 $\mathrm{BBCH})$ of spelt wheat. Weed species composition, number of weeds, and air-dry weight of the above-ground parts of weeds were determined based on sampling areas delineated by a $1 \mathrm{~m} \times 0.25 \mathrm{~m}$ frame in four randomly selected places in each plot. The obtained results were statistically analysed by analysis of variance and least significant differences were calculated using Tukey's confidence half-intervals with an error rate of $5 \%$.

\section{RESULTS}

A total of 32 dicotyledonous weed species, 6 monocotyledonous taxa, and Equisetum arvense were found to occur in the spelt wheat crops (Tables 1-3). Irrespective of the experimental factors, dicotyledonous weeds accounted on average for 56\%; among them, Galium aparine, Viola arvensis, and Matricaria maritima ssp. inodora were were represented in greatest numbers. The above-mentioned taxa accounted for, respectively, $17 \%, 10 \%$, and $8 \%$ of the total number of weeds. Among the monocotyledonous species, Apera spica venti and Setaria pumila were predominant and they constituted $25 \%$ and $16 \%$, respectively. In the studies of Kraska et al. (2009) and Pały s et al. (2011) conducted on the same soil, G. aparine, $V$. arvensis, and $A$. spica-venti were also the species that were found in the crops in greatest numbers.

The weed communities in the crops of the wheat spelt cultivars compared were composed of distinctly different numbers of species (Table 1). Depending on the cultivar, the number of weed species ranged from 24 (cv. 'Schwabenkorn') to 37 (cv. 'Spelt I.N.Z.'), but this variation related primarily to dicotyledonous weeds (respectively, 18 and 30 species). The number of weeds accompanying the spelt wheat cultivars compared differed significantly. More than two times more dicotyledonous (Fig. 1) and monocotyledonous weeds (Fig. 2) were found in the crop of the cultivar 'Spelt I.N.Z.' compared to cv. 'Schwabenkorn'. The significant differences obtained were, respectively, 26.4 plants and 21.1 plants per $1 \mathrm{~m}^{2}$. In the studies of Feledyn-Szewczyk and Duer (2005) as well as Feledyn-S zewczyk (2011), high weed competitiveness of the spelt cultivar 'Schwabenkorn', in relation to the winter wheat cultivars compared, 
resulted from the specificity of its morphological traits. This cultivar was characterized by the highest height, tillering rate, leaf area and leaf area index (LAI). Pałys and Kuraszkiewicz (2003) also found varying effects of spelt wheat cultivars on weed infestation of crops. The cultivar 'Loge' was more competitive against weeds than cv. 'Bauländer Spelz'.

The cultivation of the spelt cultivars studied resulted in significant differences in the number of individual weed species. As many as sixteen species, including the dominant weeds, occurred with lower intensity in the 'Schwabenkorn' crop compared to the cultivar 'Spelt I.N.Z.', four taxa increased their numbers, whereas fifteen weed species did not appear at all. At the same time, only 2 taxa, i.e. Amaranthus retroflexus and Eupatorium cannabinum, from the 'Schwabenkorn' crop did not have their representatives in the weed community of the 'Spelt I.N.Z.' crop. The results of many studies on cereal cultivars have shown differences in their weed competitiveness (Le merle et al. 1996, 2001; Korres and Froud-Williams, 2002; Pałys and Kuraszkiewicz, 2003; Feledyn-Szewczyk and Duer, 2005; Kraska, 2006; Parylak et al. 2006; A nd ru s z c z a k et al. 2010b).

The levels of mineral fertilization (Table 2) had no effect on the number of weed species in the crops of the spelt wheat cultivars studied (on average, 25 dicotyledonous species and 6 monocotyledonous species in each crop) (Table 2). In the studies of Fra $\mathrm{nt}$ and Bujak (2006) as well as Pałys et al. (2011), the level of mineral fertilization in winter wheat crops did not affect the number of weed species. On the other hand, mineral fertilization differentiated the floristic composition of weed communities and numbers of individual taxa. The application of higher NPK rates, at the respective amounts of 80:34.9:99.6 kg $\times$ ha $^{-1}$, increased the total number of weeds by 11.5 plants $\times \mathrm{m}^{-2}$ on average, i.e. by $20.5 \%$ compared to the fertilization level of 60:26.2:83 $\mathrm{kg} \times \mathrm{ha}^{-1}$. Eleven taxa determined the difference in weed infestation, in particular Setaria pumila and Melandrium album whose numbers were higher by 8.2 plants and 2.9 plants per $1 \mathrm{~m}^{2}$, respectively, under the conditions of more intensive mineral fertilization. Twelve weed species occurred with similar or slightly lower intensity in the plots with the lower NPK rates, while eight species were completely eliminated. But they were replaced by other taxa, among others Echinochloa crus-galli, Galinsoga parviflora, Lamium amplexicaule, and Plantago major, which were not found in the plots with less intensive fertilization. On the other hand, in the studies of Frant and Bujak (2006) as well as $\mathrm{Pałys}$ et al. (2011), the number of weeds in spring and winter wheat crops decreased as the level of mineral fertilization increased.

Weed infestation of the spelt wheat crop was significantly differentiated by the level of chemical crop protection. The application of the herbicide $\mathrm{Mu}$ stang 306 SE (treatment B) significantly reduced the number of dicotyledonous weeds per unit area - by $37 \%$ (Fig. 1), while the number of species decreased by 4 compared to the control treatment without chemical protection (treatment A) (Table 3). This herbicide effectively eliminated 7 dicotyledonous species from the crop, whereas the numbers of 10 taxa decreased. Among them, Myosotis arvensis, Papaver rhoeas, and Galium aparine were the most sensitive. The above-mentioned species responded by reducing their numbers by $73 \%, 71 \%$, and $45 \%$, respectively, under the effect of this herbicide.

The introduction of a higher level of chemical crop protection by the application of an additional herbicide (treatment $\mathrm{C}$ ) decreased the number of dicotyledonous weeds by $17.7 \%$ in relation to the control treatment, whereas the number of species was reduced to 21. Under the influence of the herbicides Mustang 306 SE and Attribut $70 \mathrm{WG}$, the majority of dicotyledonous species occurred with lower intensity than in the control plots and, moreover, 6 species were eliminated. At the same time, 4 taxa increased their proportion in the weed community, including Matricaria maritima subsp. inodora whose numbers increased more than twice.

The intensification of chemical plant protection, by applying two herbicides and a fungicide (treatment D), significantly reduced the number of dicotyledonous weeds per unit area by $34 \%$ compared to the control treatment (Fig. 1). This resulted mainly from the reduced occurrence of the following taxa: Galium aparine, Viola arvensis, Matricaria maritima subsp. inodora, Myosotis arvensis, and Papaver rhoeas. Additionally, 8 taxa were eliminated altogether. At the same time, five new species appeared, such as: Cirsium arvense, Galinsoga parviflora, Arnoseris minima, Daucus carota, and Lithospermum arvense. However, their percentage in weed infestation was low and usually did not exceed 1\% (except for Cirsium arvense). Applying Mustang 306 SE and Attribut 70 WG in a winter wheat crop grown on the same soil, K r a s k a et al. (2009) obtained a reduction in the number of dicotyledonous weeds by $41 \%$ and in the number of monocotyledonous weeds by $30 \%$ relative to the control treatment without herbicides. At the same time, they obtained different results with respect to the number of species. In the herbicide-treated plots, they found the number of both dicotyledonous and monocotyledonous taxa to have increased in relation to the control treatment. This could have resulted from the fact that under the 
conditions of herbicide application the numbers of dominant species (G. aparine and A. spica-venti) distinctly decreased, thereby enabling the emergence of new weed species from the soil seed bank.

The levels of chemical crop protection applied in the present experiment had varying effects on weed infestation by monocotyledonous species. Their total number in treatments B and C increased by $68 \%$ and $13 \%$, respectively, relative to the control treatment without chemical protection (A), whereas in treatment $\mathrm{D}$ the value of this trait was found to have decreased by 5\% (Fig. 2). In the treatment combination where the herbicide Mustang $306 \mathrm{SE}$ was used (treatment B), Setaria pumila deserves special attention (Table 3 ), since it is distinguished by a nearly sixfold increase of its proportion in the weed community (from 3.3 plants to 19.4 plants). This was probably attributable to the lack of sensitivity of this species to the active substances of the herbicide, since florasulam and 2,4-D EHE control mainly dicotyledonous weeds. At the same time, by reducing the numbers of dicotyledonous weeds, favourable conditions for the growth of monocotyledonous taxa were created. Echinochloa crus-galli and Elymus repens also showed a lack of sensitivity to the chemical agents used in the experiment, which manifested itself in an increased proportion of these taxa in the weed community. On the other hand, Apera spica-venti was found in lower numbers in the control plots. Under the effect of Attribut 70 WG (treatments C and
D), the numbers of this species decreased from $14 \%$ to $47 \%$. In the study of K r a s ka et al. (2009), depending on the applied rate of propoxycarbazone in the winter wheat crop, the numbers of $A$. spica-venti were reduced from $8 \%$ to $38 \%$.

Weed biomass, expressed by air-dry weight of the above-ground parts of weeds, was significantly dependent on the cultivar and level of chemical crop protection, whereas varying mineral fertilization did not affect this trait (Table 4). In the study of Pały s et al. (2011), dry weight of weeds in a winter wheat crop increased as the level of mineral fertilization increased. Similar results were also obtained by $\mathrm{Fr}$ a n $\mathrm{t}$ and $\mathrm{B} \mathrm{u} \mathrm{j} \mathrm{a} \mathrm{k} \mathrm{(2006)} \mathrm{in} \mathrm{spring} \mathrm{wheat} \mathrm{crops.} \mathrm{In} \mathrm{the} \mathrm{stu-}$ dies of Kraska et al. (2009) and Andrus zc zak et al. (2010a), foliar fertilization had no effect on weed infestation of cereal crops.

In the experiment in question, significantly higher weed biomass per $1 \mathrm{~m}^{2}$ was found in the crop of the cultivar 'Spelt I.N.Z.' (on average by $64 \%$ ), which can be evidence of its lower competitive ability against weeds compared to cv. 'Schwabenkorn' (Table 4). Irrespective of the cultivar and rates of mineral fertilizers, weed dry weight in all the treatments with chemical plant protection (B, C, and D) was significantly lower than in the control treatment without chemical protection, on average from $55 \%$ to $73 \%$, but the differences between the chemically protected plots were not significant.

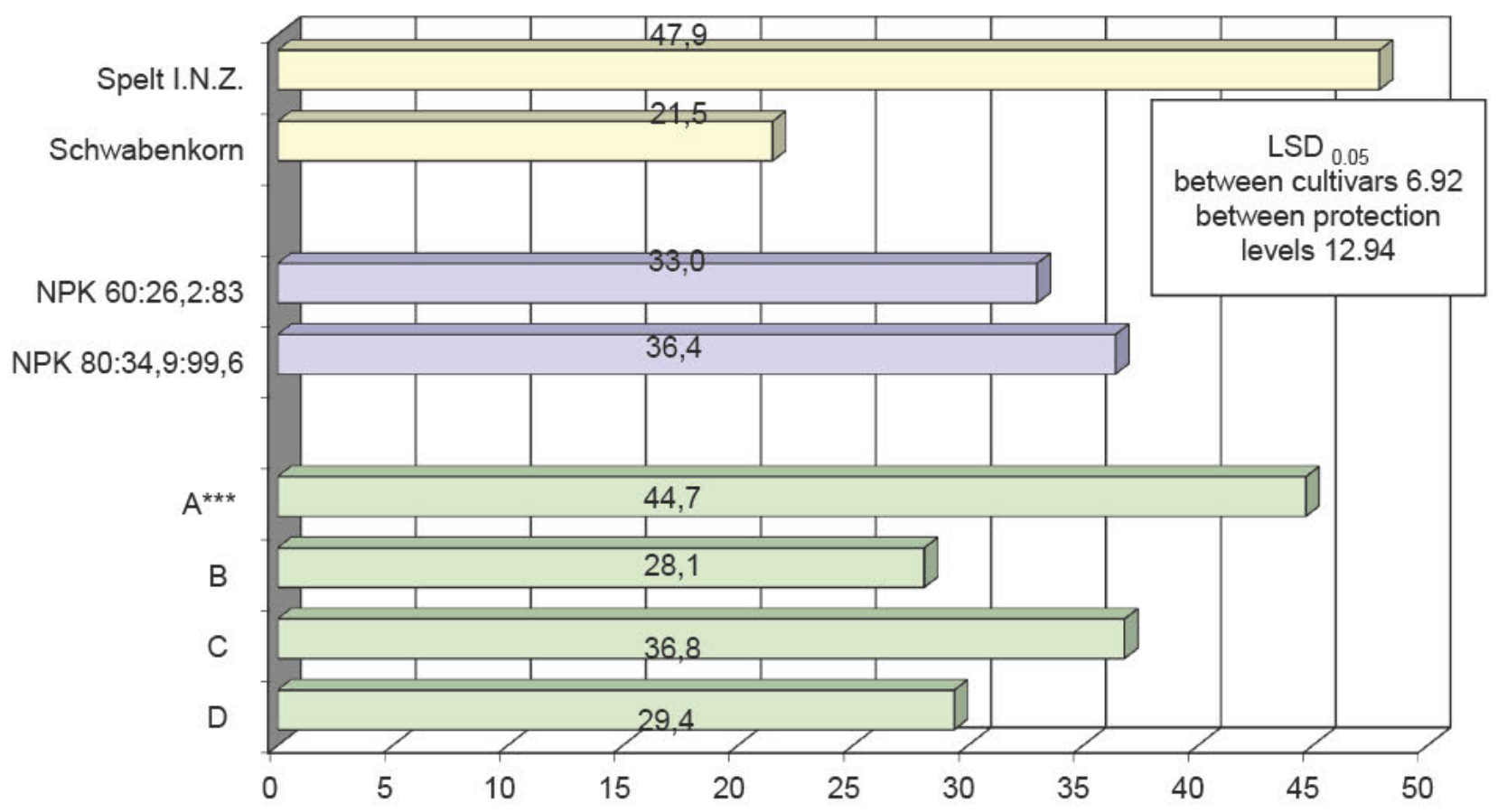

Fig. 1. Number of dicotyledonous weeds in the spelt wheat crop depending on experimental factors (plants $\times \mathrm{m}^{-2}$ ) *** Explanations as in Table 3 


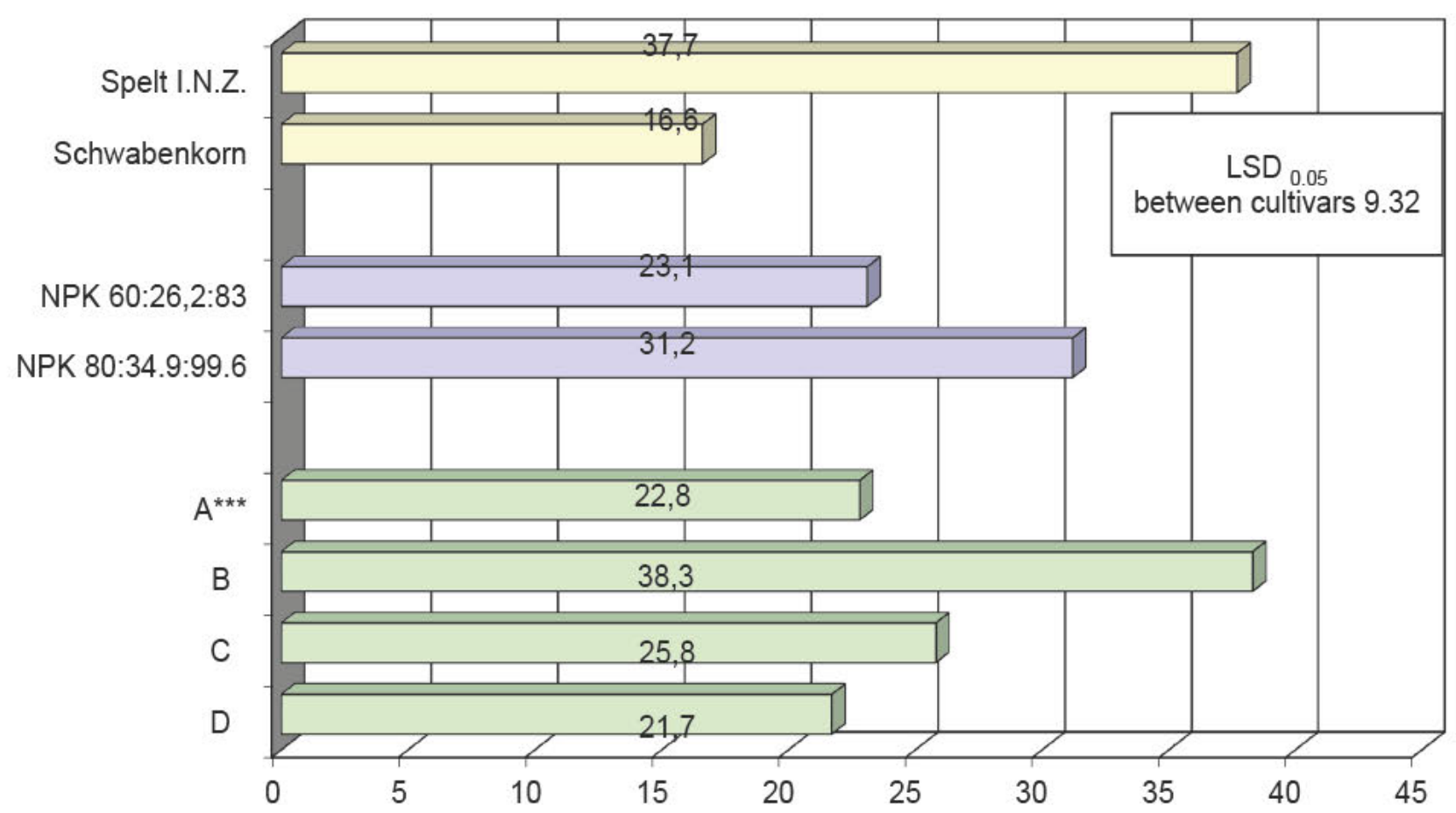

Fig. 2. Number of monocotyledonous weeds in the spelt wheat crop depending on experimental factors (plants $\left.\times \mathrm{m}^{-2}\right)$

**** Explanations as in Table 3

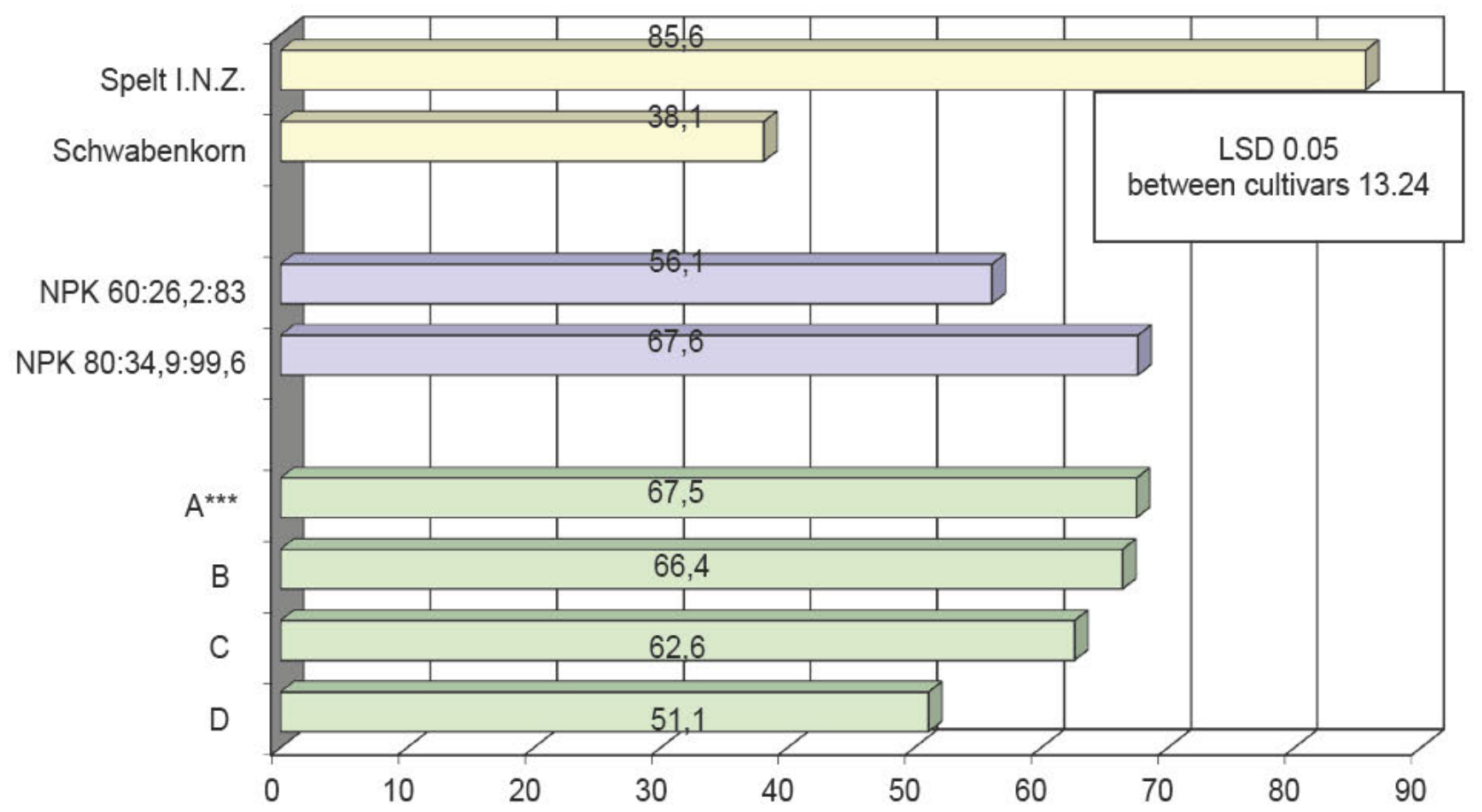

Fig. 3. Total number of weeds in the spelt wheat crop depending on experimental factors (plants $\times \mathrm{m}^{-2}$ ) 
Table 1

Number and species composition of weeds in the crops of the spelt wheat cultivars compared (plants $\times \mathrm{m}^{-2}$ )

\begin{tabular}{|c|c|c|}
\hline \multirow{2}{*}{ Weed species } & \multicolumn{2}{|c|}{ Cultivar } \\
\hline & Spelt I.N.Z & Schwabenkorn \\
\hline \multicolumn{3}{|l|}{ Dicotyledonous } \\
\hline Galium aparine $\mathrm{L}$. & 13.9 & 7.5 \\
\hline Viola arvensis Murray & 8.1 & 3.8 \\
\hline Matricaria maritima subsp. inodora (L.) & 7.9 & 2.3 \\
\hline Fallopia convolvulus L. & 3.1 & 1.1 \\
\hline Veronica agrestis L. & 3.1 & 0.5 \\
\hline Melandrium album (Mill.) Garcke & 3.0 & 0.1 \\
\hline Myosotis arvensis (L.) Hill & 1.5 & 1.3 \\
\hline Sonchus arvensis L. & 1.2 & 0.2 \\
\hline Papaver rhoeas L. & 1.1 & 1.3 \\
\hline Cirsium arvense (L.) Scop. & 0.9 & - \\
\hline Convolvulus arvensis L. & 0.8 & 2.3 \\
\hline Stellaria media (L.) Vill. & 0.5 & 0.1 \\
\hline Veronica persica Poir. & 0.5 & - \\
\hline Chenopodium album $\mathrm{L}$. & 0.3 & 0.1 \\
\hline Polygonum aviculare L. & 0.3 & 0.0 \\
\hline Galeopsis tetrahit Mill. & 0.3 & - \\
\hline Galinsoga parviflora Cav. & 0.2 & 0.4 \\
\hline Solanum tuberosum L. & 0.2 & 0.2 \\
\hline Fraxinus excelsior L. (juv.) & 0.2 & - \\
\hline Lamium amplexicaule $\mathrm{L}$. & 0.2 & - \\
\hline Plantago major L. & 0.2 & - \\
\hline Arctium tomentosum Mill. & 0.1 & - \\
\hline Arnoseris minima (L.) Schweigg. \& Körte & 0.1 & - \\
\hline Artemisia vulgaris L. & 0.1 & - \\
\hline Conyza canadensis (L.) Cronquist & 0.1 & - \\
\hline Anagallis arvensis L. & $0.0 * *$ & 0.2 \\
\hline Capsella bursa-pastoris (L.) Medik. & 0.0 & - \\
\hline Daucus carota $\mathrm{L}$. & 0.0 & - \\
\hline Fumaria officinalis L. & 0.0 & - \\
\hline Lithospermum arvense $\mathrm{L}$. & 0.0 & - \\
\hline Amaranthus retroflexus $\mathrm{L}$. & - & 0.1 \\
\hline Eupatorium cannabinum L. & - & 0.0 \\
\hline Number of dicotyledonous weeds & 30 & 18 \\
\hline \multicolumn{3}{|l|}{ Monocotyledonous* } \\
\hline Apera spica-venti (L.) P. Beauv. & 22.0 & 8.5 \\
\hline Setaria pumila (Poir.) Roem. \& Schult. & 12.0 & 7.4 \\
\hline Echinochloa crus-galli (L.) P. Beauv. & 1.6 & 0.1 \\
\hline Equisetum arvense $\mathrm{L}$. & 1.4 & 0.2 \\
\hline Elymus repens (L.) Gould & 0.4 & 0.3 \\
\hline Pоа аппиа $\mathrm{L}$. & 0.2 & - \\
\hline Avena fatua $\mathrm{L}$. & 0.1 & 0.1 \\
\hline Number of monocotyledonous weeds & 7 & 6 \\
\hline Total number of species & 37 & 25 \\
\hline
\end{tabular}

* Monocotyledonous weeds together with Equisetum arvense

$0.0 * *$ Species occurring at less than 0.1 plants $\times \mathrm{m}^{-2}$ 
Table 2

Number and species composition of weeds in the spelt wheat crop depending on the level of mineral fertilization $\left(\right.$ plants $\times \mathrm{m}^{-2}$ )

\begin{tabular}{|c|c|c|}
\hline \multirow{2}{*}{ Weed species } & \multicolumn{2}{|c|}{ Mineral fertilization level } \\
\hline & NPK 60:26.2:83 & NPK 80:34.9:99.6 \\
\hline \multicolumn{3}{|l|}{ Dicotyledonous } \\
\hline Galium aparine $\mathrm{L}$. & 11.3 & 10.1 \\
\hline Viola arvensis Murray & 7.2 & 4.7 \\
\hline Matricaria maritima subsp. inodora (L.) & 4.9 & 5.4 \\
\hline Convolvulus arvensis L. & 1.8 & 1.3 \\
\hline Myosotis arvensis (L.) Hill & 1.3 & 1.5 \\
\hline Fallopia convolvulus L. & 1.1 & 3.1 \\
\hline Papaver rhoeas L. & 1.1 & 1.3 \\
\hline Veronica agrestis $\mathrm{L}$. & 1.0 & 2.6 \\
\hline Cirsium arvense (L.) Scop. & 0.8 & 0.0 \\
\hline Sonchus arvensis L. & 0.4 & 1.0 \\
\hline Stellaria media (L.) Vill. & 0.4 & 0.2 \\
\hline Veronica persica Poir. & 0.3 & 0.3 \\
\hline Galeopsis tetrahit Mill. & 0.3 & - \\
\hline Solanum tuberosum L. & 0.3 & - \\
\hline Polygonum aviculare $\mathrm{L}$. & 0.2 & 0.2 \\
\hline Melandrium album (Mill.) Garcke & 0.1 & 3.0 \\
\hline Chenopodium album $\mathrm{L}$. & 0.1 & 0.2 \\
\hline Fraxinus excelsior L. (juv.) & 0.1 & 0.2 \\
\hline Anagallis arvensis $\mathrm{L}$. & 0.1 & 0.1 \\
\hline Amaranthus retroflexus $\mathrm{L}$. & 0.1 & - \\
\hline Arnoseris minima (L.) Schweigg. \& Körte & 0.1 & - \\
\hline Arctium tomentosum Mill. & $0.0 * *$ & 0.0 \\
\hline Daucus carota $\mathrm{L}$. & 0.0 & - \\
\hline Eupatorium cannabinum $\mathrm{L}$. & 0.0 & - \\
\hline Fumaria officinalis L. & 0.0 & - \\
\hline Galinsoga parviflora Cav. & - & 0.6 \\
\hline Lamium amplexicaule $\mathrm{L}$. & - & 0.2 \\
\hline Plantago major L. & - & 0.2 \\
\hline Artemisia vulgaris $\mathrm{L}$. & - & 0.1 \\
\hline Conyza canadensis (L.) Cronquist & - & 0.1 \\
\hline Capsella bursa-pastoris (L.) Medik. & - & 0.0 \\
\hline Lithospermum arvense $\mathrm{L}$. & - & 0.0 \\
\hline Number of dicotyledonous weeds & 25 & 25 \\
\hline \multicolumn{3}{|l|}{ Monocotyledonous* } \\
\hline Apera spica-venti (L.) P. Beauv. & 15.5 & 15.0 \\
\hline Setaria pumila (Poir.) Roem. \& Schult. & 5.6 & 13.8 \\
\hline Equisetum arvense $\mathrm{L}$. & 1.5 & 0.1 \\
\hline Elymus repens (L.) Gould & 0.2 & 0.5 \\
\hline Poa апnиа $\mathrm{L}$. & 0.2 & - \\
\hline Avena fatua $\mathrm{L}$. & 0.1 & 0.1 \\
\hline Echinochloa crus-galli (L.) P. Beauv. & - & 1.7 \\
\hline Number of monocotyledonous weeds & 6 & 6 \\
\hline Total number of species & 31 & 31 \\
\hline
\end{tabular}

*; $0.0 * *$ Explanations as in Table 1 
Table 3

Number and species composition of weeds in the spelt wheat crop depending on the level of chemical protection $\left(\right.$ plants $\times \mathrm{m}^{-2}$ )

\begin{tabular}{|c|c|c|c|c|}
\hline \multirow{2}{*}{ Weed species } & \multicolumn{4}{|c|}{ Chemical protection level } \\
\hline & $\mathrm{A} * * *$ & $\mathrm{~B}$ & $\mathrm{C}$ & $\mathrm{D}$ \\
\hline \multicolumn{5}{|l|}{ Dicotyledonous } \\
\hline Galium aparine $\mathrm{L}$. & 17.4 & 9.5 & 9.3 & 6.6 \\
\hline Viola arvensis Murray & 7.1 & 6.3 & 5.3 & 5.1 \\
\hline Matricaria maritima subsp. inodora (L.) & 4.4 & 3.1 & 9.9 & 3.2 \\
\hline Myosotis arvensis (L.) Hill & 2.6 & 0.7 & 1.3 & 0.8 \\
\hline Papaver rhoeas $\mathrm{L}$. & 2.4 & 0.7 & 0.8 & 0.8 \\
\hline Fallopia convolvulus L. & 2.2 & 1.8 & 2.9 & 1.5 \\
\hline Convolvulus arvensis $\mathrm{L}$. & 2.1 & 1.3 & 1.2 & 1.6 \\
\hline Veronica agrestis $\mathrm{L}$. & 1.7 & 1.7 & 1.0 & 2.8 \\
\hline Melandrium album (Mill.) Garcke & 1.3 & 1.0 & 1.2 & 2.7 \\
\hline Stellaria media (L.) Vill. & 0.9 & 0.1 & 0.2 & - \\
\hline Sonchus arvensis L. & 0.4 & 0.4 & 0.9 & 1.0 \\
\hline Solanum tuberosum L. & 0.4 & - & 0.2 & - \\
\hline Fraxinus excelsior L. (juv.) & 0.2 & 0.3 & 0.1 & - \\
\hline Galeopsis tetrahit Mill. & 0.2 & 0.2 & 0.0 & 0.2 \\
\hline Anagallis arvensis $\mathrm{L}$. & 0.2 & 0.2 & - & 0.1 \\
\hline Chenopodium album $\mathrm{L}$. & 0.2 & 0.1 & 0.2 & 0.2 \\
\hline Plantago major $\mathrm{L}$. & 0.2 & - & 0.1 & 0.1 \\
\hline Lamium amplexicaule $\mathrm{L}$. & 0.2 & - & - & 0.2 \\
\hline Conyza canadensis (L.) Cronquist & 0.2 & - & - & - \\
\hline Polygonum aviculare L. & 0.1 & 0.1 & 0.5 & 0.1 \\
\hline Artemisia vulgaris L. & 0.1 & 0.1 & - & - \\
\hline Arctium tomentosum Mill. & 0.1 & - & 0.1 & - \\
\hline Capsella bursa-pastoris (L.) Medik. & 0.1 & - & - & - \\
\hline Eupatorium cannabinum L. & $0.0 * *$ & - & - & - \\
\hline Veronica persica Poir. & - & 0.2 & 0.9 & - \\
\hline Galinsoga parviflora Cav. & - & 0.2 & 0.6 & 0.4 \\
\hline Fumaria officinalis L. & - & 0.1 & - & - \\
\hline Amaranthus retroflexus $\mathrm{L}$. & - & - & 0.1 & - \\
\hline Cirsium arvense (L.) Scop. & - & - & - & 1.6 \\
\hline Arnoseris minima (L.) Schweigg. \& Körte & - & - & - & 0.2 \\
\hline Daucus carota $\mathrm{L}$. & - & - & - & 0.1 \\
\hline Lithospermum arvense $\mathrm{L}$. & - & - & - & 0.1 \\
\hline Number of dicotyledonous weeds & 24 & 20 & 21 & 21 \\
\hline \multicolumn{5}{|l|}{ Monocotyledonous* } \\
\hline Apera spica-venti (L.) P. Beauv. & 18.4 & 17.1 & 15.8 & 9.8 \\
\hline Setaria pumila (Poir.) Roem. \& Schult. & 3.3 & 19.4 & 8.3 & 7.8 \\
\hline Equisetum arvense $\mathrm{L}$. & 0.7 & 0.3 & - & 2.2 \\
\hline Echinochloa crus-galli (L.) P. Beauv. & 0.2 & 0.6 & 0.8 & 1.8 \\
\hline Elymus repens (L.) Gould & 0.1 & 0.4 & 0.8 & 0.1 \\
\hline Avena fatua $\mathrm{L}$ & 0.1 & 0.2 & 0.1 & - \\
\hline Pоа аппиа $\mathrm{L}$. & - & 0.3 & - & - \\
\hline Number of monocotyledonous weeds & 6 & 7 & 5 & 5 \\
\hline Total number of species & 30 & 27 & 26 & 26 \\
\hline
\end{tabular}

*; $0.0 * *$ Explanations as in Table 1

*** A. Control treatment (without chemical protection); B. Mustang 306 SE + Stabilan 750 SL; C. Mustang 306 SE + Attribut 70 WG + Stabilan 750 SL; D. Mustang 306 SE + Attribut 70 WG + Alert 375 SC + Stabilan 750 SL 
Table 4

Air-dry weight of the above-ground parts of weeds in the crops of the spelt wheat cultivars compared $\left(\mathrm{g} \times \mathrm{m}^{-2}\right)$

\begin{tabular}{|c|c|c|c|c|c|c|c|c|c|}
\hline \multirow{3}{*}{$\begin{array}{c}\text { Chemical } \\
\text { protection } \\
\text { level }\end{array}$} & \multicolumn{3}{|c|}{ Spelt I.N.Z. } & \multicolumn{3}{|c|}{ Schwabenkorn } & \multicolumn{3}{|c|}{ Mean } \\
\hline & \multicolumn{9}{|c|}{ Fertilization level } \\
\hline & $\begin{array}{c}\text { NPK } \\
60: 26.2: 83\end{array}$ & $\begin{array}{c}\text { NPK } \\
80: 34.9: 99.6\end{array}$ & Mean & $\begin{array}{c}\text { NPK } \\
60: 26.2: 83\end{array}$ & $\begin{array}{c}\text { NPK } \\
80: 34.9: 99.6\end{array}$ & Mean & $\begin{array}{c}\text { NPK } \\
60: 26.2: 83\end{array}$ & $\begin{array}{c}\text { NPK } \\
\text { 80:34.9:99.6 }\end{array}$ & Mean \\
\hline $\mathrm{A} * * *$ & 44.9 & 35.1 & 40.0 & 22.9 & 26.9 & 24.9 & 33.9 & 31.0 & 32.4 \\
\hline $\mathrm{B}$ & 14.1 & 17.4 & 15.7 & 17.1 & 10.1 & 13.6 & 15.6 & 13.7 & 14.7 \\
\hline $\mathrm{C}$ & 14.0 & 20.1 & 17.1 & 6.0 & 9.0 & 7.5 & 10.0 & 14.6 & 12.3 \\
\hline $\mathrm{D}$ & 9.6 & 13.9 & 11.7 & 4.4 & 6.6 & 5.5 & 7.0 & 10.2 & 8.6 \\
\hline Mean & 20.6 & 21.6 & 21.1 & 12.6 & 13.1 & 12.9 & 16.6 & 17.4 & - \\
\hline $\operatorname{LSD}_{0.05}$ & $\begin{array}{l}\text { between cul } \\
\text { between pro }\end{array}$ & $\begin{array}{l}\text { ltivars } 5.81 \\
\text { otection levels }\end{array}$ & & & & & & & \\
\hline
\end{tabular}

*** Explanations as in Table 3

** Explanations as in Table 3

\section{CONCLUSIONS}

1. The floristic composition and numbers of weeds colonising the spelt wheat crops depended primarily on the cultivar and level of chemical crop protection and to a smaller extent on mineral fertilization rates.

2. Irrespective of the experimental factors, Apera spica-venti $(25 \%)$ and Setaria pumila $(16 \%)$ had the highest percentages in the monocotyledonous class, while Galium aparine (17\%) among the dicotyledonous weed species.

3. The number of both monocotyledonous and dicotyledonous weeds, total number of weeds and air-dry weight of the above-ground parts of weeds in the crop of the cultivar 'Schwabenkorn' were significantly lower compared to cv. 'Spelt I.N.Z.' .

4. The higher level of mineral fertilization slightly increased the number of weeds in the spelt crop, but it had no effect on weed dry weight and number of weed species.

5. Compared to the control treatment without chemical protection, air-dry weight of the above-ground parts of weeds decreased as the level of chemical plant protection increased. At the same time, the value of this trait in the chemically protected plots did not differ significantly.

\section{Acknowledgements}

Research supported by the Ministry of Science and Higher Education of Poland as the part of statutory activities of Department of Agricultural Ecology, University of Life Sciences in Lublin.

\section{REFERENCES}

Andruszczak S., Kraska P., Kwiecińska-Poppe E., Pałys E. 2010a. Biological diversity of we- eds in a winter triticale (Triticum rimpaui Wittm.) crop depending on different doses of herbicides and foliar fertilization. Acta Agrob. 64(2): 109-118.

Andruszczak S., Kwiecińska-Poppe E., Kraska P., Pałys E. 2010b. The effect of different agrotechnical levels on weed infestation in crops of naked and husked varieties of oat (Avena sativa L.). Acta Agrob. 63(2): 207-213.

Adamczewski K., Praczyk T. 1999. Strategy of weed control in small grain cereals. Pam. Pul. 114: 5-13.

Beres B.L., Harker K.N., Clayton G.W., Bremer E., Blackshaw R.E., Graf R.J. 2010. Weed-competitive ability of spring and winter cereals in the Northern Great Plains. Weed Tech. 24(2): 108-116.

Blecharczyk A., Małecka I., Sawinska Z., Zawa d a D. 2009. Effect of fertilization on weed biodiversity in long-term continuous winter rye. Prog. Plant Protection / Post. Ochr. Roślin 49(1): 322-325.

Christensen S. 1995. Weed suppression ability of spring barley varieties. Weed Res. 35: 241-247.

Feledy n-S zew c z y k B . 2011. Zachwaszczenie i plonowanie pszenicy orkisz na tle współczesnych odmian pszenicy zwyczajnej w ekologicznym systemie produkcji. Mat. Konf. Nauk. „Hodowla, uprawa i wykorzystanie pszenicy orkisz w warunkach zmian klimatu". Puławy, 28-29 czerwiec: 13-14 (in Polish).

Feledyn-Szewczyk B., Duer I. 2005. Konkurencyjność kilku odmian pszenicy ozimej uprawianej w ekologicznym systemie produkcji w stosunku do chwastów. / Weed competitiveness of some winter wheat varieties cultivated in an organic crop production system. Prog. Plant Protection / Post. Ochr. Roślin 45(1): 126-133 (in Polish).

Feledyn-Szewczyk B., Duer I. 2006. Assessment of weed competitiveness in relation to some winter wheat varieties cultivated in organic crop production system. J. Res. Appl. Agricult. Engin. 51(2): 30-35. 
Frant M., Bujak K. 2006. Wpływ uproszczeń w uprawie roli i poziomów nawożenia mineralnego na zachwaszczenie pszenicy jarej. / Influence of reduced tillage and levels of fertilization on spring wheat weed infestation. Acta Agroph. 8(2): 327-336 (in Polish).

Gawrońska-Kulesza A., Lenart S., Suwara I. 2005. The effect of crop rotation and fertilization on the weediness of canopy and soil. Fragm. Agronom. 2: 5362.

Jędruszczak M., Bojarczyk M., Smolarz H., Budzyńska B. 2004. Competitive ability of winter wheat to weeds under different weed control measures - biomass production. Ann. UMCS, Sect. E, 59(2): 895902.

Korres N.E., Froud-Williams R.J.2002. Effects of winter wheat cultivars and seed rate on the biological characteristics of naturally occurring weed flora. Weed Res. 42: 417-428.

K ra s k a P. 2006. Wpływ zróżnicowanych dawek herbicydów na zachwaszczenie pszenicy ozimej. / The influence of different herbicide doses on winter wheat weed infestation. Prog. Plant Protection / Post. Ochr. Roślin 46(2): 256-260 (in Polish).

Kraska P., Pałys E. 2007. Weed infestation of winter rye canopy dependent on different cultivation technology. Acta Agroph. 10(2): 397-405.

Kraska P., Okoń S., Pałys E. 2009. Weed infestation of a winter wheat canopy under the conditions of application of different herbicide doses and foliar fertilization. Acta Agrobot. 62 (2): 193-206.

Lemerle D., Verbeek B., Cousens R.D., Coombes N.E. 1996. The potential for selecting wheat varieties strongly competitive against weeds. Weed Res. 36: 505-513.

Lemerle D., Verbeek B., Orchard B. 2001. Ranking the ability of wheat varieties to compete with $\mathrm{Lo}$ lium rigidum. Weed Res. 41: 197-209.

Pałys E., Korzeniowski M., Andruszczak S., Kraska P., Krusińska B. 2011. Wpływ poziomu nawożenia mineralnego i ochrony chemicznej na zachwaszczenie łanu pszenicy ozimej wysiewanej po sobie na rędzinie. / The influence of mineral fertilization and chemical protection on weed infestation of winter wheat sown after winter wheat on rendzina soil. Zesz. Prob. Post. Nauk Rol. 559: 141-151 (in Polish).

Pałys E., Kuraszkiewicz R. 2003. Wpływ terminów siewu odmian orkiszu (Triticum aestivum ssp. spelta) na zachwaszczenie łanu. / The influence of sowing date on the weed infestation of spelt canopy. Zesz. Post. Nauk Rol. 490: 179-186 (in Polish).

Parylak D., Zawieja J., Jędruszczak M., Stupnicka-Rodzynkiewicz E., Dąbkowska T., Snarska K. 2006. Wykorzystanie zasiewów mieszanych, właściwości odmian lub zjawiska allelopatii w ograniczaniu zachwaszczenia. / Use of the mixed crops, cultivar properties or allelopathy in weed control. Prog. Plant Protection / Post. Ochr. Roślin, 46 (1): 33-44 (in Polish).
Sulewska H. 2004. Characterization of 22 spelt (Triticum aestivum ssp. spelta) genotypes relating to some features. Biul. IHAR, 231: 43-53.

\section{Zachwaszczenie lanu ozimych odmian pszenicy orkisz (Triticum aestivum ssp. Spelta) uprawianych w zróżnicowanych warunkach nawożenia mineralnego i ochrony chemicznej}

\section{Streszczenie}

Doświadczenie polowe przeprowadzono w latach 2008-2010 na rędzinie mieszanej wytworzonej z opoki kredowej. Celem badań była ocena zachwaszczenia ozimych odmian pszenicy orkiszowej (Schwabenkorn i Spelt I.N.Z.) uprawianych w zróżnicowanych warunkach nawożenia mineralnego i ochrony chemicznej. Nawożenie mineralne przedstawiało się następująco (w kg czystego składnika na hektar): I. N 60; P 26,2; K 83 oraz II. N 80; P 34,9; K 99,6. Poziomy ochrony roślin obejmowały: A. Obiekt kontrolny; B. Mustang 306 SE, Stabilan 750 SL; C. Mustang 306 SE, Attribut 70 WG, Stabilan 750 SL; D. Mustang 306 SE, Attribut 70 WG, Alert 375 SC, Stabilan 750 SL.

Największy udział w zbiorowisku chwastów, niezależnie od czynników doświadczenia, miały Apera spica-venti i Setaria pumila z klasy jednoliściennych, $\mathrm{z}$ dwuliściennych zaś Galium aparine. Bardziej konkurencyjna wobec chwastów była odmiana Schwabenkorn. Zarówno liczba chwastów dwuliściennych, jednoliściennych i ogółem, jak i powietrznie sucha masa części nadziemnych chwastów w łanie tej odmiany były istotnie mniejsze w porównaniu z odmianą Spelt I.N.Z. Zastosowane chemiczne zabiegi ochrony roślin zmniejszyły powietrznie suchą mase nadziemnych części chwastów w odniesieniu do obiektu kontrolnego bez ochrony. Wyższy poziom nawożenia mineralnego nieznacznie zwiększył liczbę chwastów w łanie orkiszu, nie miał jednak wpływu na ich powietrznie suchą masę oraz liczbę gatunków chwastów. 